U.S. DEPARTMENT OF THE INTERIOR

U.S. GEOLOGICAL SURVEY

\title{
GEOLOGIC MAP AND FOLD- AND THRUST-BELT INTERPRETATION OF THE SOUTHEASTERN PART OF THE CHARLEY RIVER QUADRANGLE, EAST-CENTRAL ALASKA
}

By James H. Dover 


\title{
GEOLOGIC MAP AND FOLD- AND THRUST-BELT INTERPRETATION OF THE SOUTHEASTERN PART OF THE CHARLEY RIVER QUADRANGLE, EAST-CENTRAL ALASKA
}

\author{
By James H. Dover
}

\section{INTRODUCTION}

This report presents the geologic map evidence for the interpretation of the Charley River region as a fold and thrust belt. Stratigraphic problems bearing on the rigor of this interpretation are briefly reviewed, and some regional tectonic implications of the fold and thrust belt model-including the interaction of the fold and thrust belt with the Tintina strike-slip fault zone, are also discussed.

\section{PREVIOUS WORK}

Geologic observations were first made in the Charley River region by pioneering Alaskan geologists such as Prindle (1905, 1906, 1913), Kindle (1908), Brooks and Kindle (1908), and Cairnes (1914), but the reconnaissance studies of Mertie $(1930,1932,1937)$ form the foundation for more recent geologic investigations in eastcentral Alaska. For the past 20 years, the work of Brabb and Churkin has served as the geologic standard for the area considered here. The structural re-evaluation in this report depends heavily on the distribution of rock units mapped by Brabb and Churkin (1969) and on the stratigraphic relations worked out during the course of their mapping (Brabb, 1967, 1969; Brabb and Churkin, 1967; Churkin and Brabb, 1965a,b). However, important aspects of the rock distribution and contact relations they mapped are not readily explained by the pattern and style of normal faulting adopted on their map. The explanation for these discrepancies seems to require a far more complex structural framework than is generally recognized. Reconnaissance petroleum and mineral exploration by company geologists during the past 10 years has led to the realization that thrust faulting was an important deformational mechanism in the Charley River quadrangle and adjacent areas (Bruce Clardy, oral commun., 1982; Gardner and others, 1984), and recent work suggests that the area lies within an extension of the northern Cordilleran fold and thrust belt of Canada (Dover, 1985a; Dover and Miyaoka, 1988). Norris (1979) mapped a comparable style of folding and thrusting in the Ogilvie River 1:250,000 quadrangle in adjacent Yukon Territory.

\section{CONTENT AND PROCEDURE}

The area of the Charley River 1:250,000 quadrangle considered in this report is encompassed within eight $1: 63,360$ (1 in. = $1 \mathrm{mi}$.) quadrangles (index map, sheet 1 ).
The report contains a geologic map and interpretive cross sections (scale 1:100,000, sheets 1 and 2, respectively), and a small-scale tectonic map showing regional structural continuity and trends (scale 1:500,000, fig. 4, sheet 2).

The geologic map contains considerable detail compiled from more than 1,000 field stations (fig. 1, sheet 1). Nearly 85 percent of these stations and their included data are recompiled directly from the original field notes and field sheets (1960-63, 1967-68, 1973) of Brabb and Churkin. The new data were collected during parts of four field seasons, from 1982 to 1985, and involve a total of 25 days of helicopter-supported field work, concentrated largely in localities where pre-existing data were scarce, or in localities judged from previous work to be critical to structural interpretation. The main contribution of this report is in the re-evaluation and analysis of pre-existing data in light of new information and alternative tectonic models, and as a result, in the recasting of the structural framework in terms of fold- and thrust-belt structural styles. However, because much of the earlier data is unchecked, and because significant holes in map coverage still exist, this geologic map is regarded as of detailed reconnaissance quality only. Descriptions of stratigraphic units used on this map are generally brief because of the reliance on previously defined stratigraphic subdivisions. Far more complete unit descriptions can be found in the stratigraphic reports of Brabb and Churkin already mentioned, and also in stratigraphic reports by Clough and Blodgett (1984), Young (1982), and Laudon and others (1966). The distribution of units shown on the geologic map (sheet 1 ) is supported by fossil data compiled by Miyaoka (1990).

The interpretive cross sections (sheet 2) illustrate the fold and thrust styles and geometry considered to characterize the map area. The sections were constructed from surface data according to basic rules of thrust geometry described by Dahlstrom (1970) and Royse and others (1975). The family of structures illustrated is defined by field observations, and includes concentric folds, imbricate low-angle thrust faults with bedding-parallel and ramped segments, a duplex system, and late listric normal faults. However, the sections cannot be rigorously balanced because of serious data limitations, some of which are (1) lack of subsurface information, (2) poor surface map control in places, (3) locally questionable unit identifications, (4) generally poor constraints on formation 
thicknesses and facies variations, and (5) the probability of inadequately defined major unconformities at several stratigraphic horizons. Even though the sections are highly conceptual, I am encouraged by the degree to which the fold- and thrust-belt model can be applied to cross-section construction without seriously compromising rules of construction or violating surface geologic controls, even in this preliminary and poorly constrained stage. Some specific geologic aspects and implications of the structure sections are discussed in the report.

The tectonic map (fig. 4, sheet 2) shows at reduced scale my interpretation of the structural continuity and regional changes in major fold and thrust trends between the Charley River and adjacent Eagle, Dawson, and Ogilvie River quadrangles. Geologic relations in the western Charley River quadrangle are extensively modified from Brabb and Churkin (1969) based on my own unpublished data. The structural interpretation of the northeastern Eagle quadrangle and the Dawson quadrangle northeast of the Tintina fault is modified from maps published by Foster (1976), Brabb and Churkin (1965), and Green and Roddick (1961). The geology of the Ogilvie River quadrangle is after Norris (1979). All abbreviations of named structures cited in parentheses in the text are shown on figure 4.

\section{CHARLEY RIVER FOLD AND THRUST BELT STRUCTURAL FRAMEWORK}

The overall fold- and thrust-belt framework of the southeastern Charley River area can be recognized from the distribution and pattern of repetition of key units on the geologic map (sheet 1). Three prominent belts of the same Middle Proterozoic to Triassic rock sequence extend from southwest to northeast across the center of the map area. The key stratigraphic units include (1) Late Proterozoic and Lower Cambrian(?) strata, which include Oldhamia-bearing beds in two of the belts, and basaltic volcanic rocks and red beds in all three belts, and (2) rocks of the Permian Tahkandit Limestone, and limestone and shale of the Triassic lower part of the Glenn Shale. The distribution of mapped units indicates that the stratigraphic sequence contained in these belts is bounded and repeated by major, moderate- to low-angle, northwest-dipping, older-on-younger thrust faults. Numerous imbricate fault splays complicate the internal structure of each of the thrust-bounded belts, but the principal sole thrusts are (from structurally lowest to highest) the Three Castle Mountain (TCT), Fourth of July Creek (FJT), Waterfall Creek (WCT), and Nation River (NRT) thrust systems (see cross sections $B-B^{\prime}$ and $C-C^{\prime}$, sheet 2). Besides these major sequence-repeating structures, subsidiary older-onyounger thrusts with at least modest stratigraphic offsets include the Montauk Bluff thrust (MBT), some horses within the Hard Luck duplex (HLD), the Nation Reef (NFT) and Logan Creek (LCT) thrust splays of the Nation River thrust system, the Kathul Mountain thrust (KMT), and some unnamed thrusts within the Kandik sequence.

In the northeastern Charley River B-1 and southeastern $\mathrm{C}-1$ quadrangles, two splays of the Yukon thrust of Norris (1979) place the Cambrian and Ordovician Jones Ridge Formation over the Devonian Nation River Formation, and locally over the Permian Tahkandit. Limestone. A lower, unnamed splay of the Yukon thrust system brings the Nation River Formation and Permian Step Conglomerate over Lower Cretaceous rocks tentatively assigned to the Kathul Graywacke. To the southeast, in Yukon Territory (fig. 4, sheet 2), where these splays merge, stratigraphic throw on the Yukon thrust increases, and Proterozoic rocks of the Tindir Group override a unit mapped by Norris as the middle member of the Upper Cretaceous to Tertiary Monster Formation, but for which Cushing and others (oral commun., 1986) report an Early Cretaceous age. Map and cross-section relations suggest the Yukon thrust developed from a detachment within or below the lower part of the Tindir (see Gardner and others, 1984), and that it may form the sole for structurally higher thrusts, including all the thrust faults within the southeastern Charley River map area.

In the southeastern part of the map area, the two most prominent thrusts involving older-on-younger displacements are a southeastern extension of the Three Castle Mountain thrust (TCT), which in this area brings Late Proterozoic basalt and red beds of the upper part of the Tindir over rocks as young as Middle Devonian, and a continuation of the Yukon thrust (YT) along which the Cambrian and Ordovician Jones Ridge Limestone section at Squaw Peak overrides the Devonian McCann Hill Chert.

Several other prominent thrust faults involving olderon-younger displacements are mapped in the western Charley River 1:250,000 quadrangle (fig. 4, sheet 2). These include (1) the Andrews Creek thrust (ACT), along which the Lower Cretaceous upper part of the Glenn Shale and Lower Cretaceous Keenan Quartzite override the stratigraphically overlying Biederman Argillite, (2) the Threemile Creek (TMT) and Snowy Peak (SPT) thrusts, which bring the Devonian Nation River Formation and(or) Permian Step Conglomerate over the Lower Cretaceous Kandik Group, and (3) an unnamed thrust to the northwest of Snowy Peak, along which Middle Devonian (and older?) rocks override rocks tentatively assigned to the Upper Devonian Nation River Formation.

Thrust fault zones are rarely exposed. Most thrust faults are interpreted from mapped truncations of rock units. However, breccia and slickensides related to thrust zones are present locally, and small-scale internal folding and shearing produced by differential movement between rock units within thrust sheets are common, especially in weak, typically shaly units.

The spatial distribution of folds and thrust faults, and the location of some thrusts in the axial zones of major folds clearly indicate a genetic relation between folding and thrusting. Most major folds, including the Kathul Mountain syncline (KMS), Hard anticline and syncline (HA,HS), Indian Grave syncline (IGS), Half fold belt (HFB), Nation anticline (NA), Tatonduk Creek anticline and syncline (TCA,TCS), and Windfall Mountain syncline (WMS), occur above regional thrust faults (fig. 4 and cross sections, sheet 2). Although the precise kinematic relation between folding and thrusting is unknown for many folds, some 
major folds are inferred from map and cross-section relations to occur above ramped segments of underlying thrust surfaces, and probably formed in response to thrusting. The two best examples are the Step Mountain anticline (SMA) and the Cathedral Creek arch (CCA), on cross sections $A-A^{\prime}$ and $C-C^{\prime}$, respectively (sheet 2 ). On the other hand, folds with axial thrusts, like the Indian Grave and Hard synclines; suggest thrusting as a result of or concurrent with the folding process.

\section{DIRECTION AND AMOUNT OF TECTONIC TRANSPORT}

Most thrust faults in the southeastern Charley River quadrangle have northeast trends and underwent tectonic transport toward the southeast (fig. 4 and cross sections $A-A^{\prime}, B-B^{\prime}$, and $C-C^{\prime}$, sheet 2$)$; a few northwest-directed back thrusts are mapped along upper Nation River, and are mapped by Norris (1979) in the Ogilvie River quadrangle. The direction of tectonic transport is indicated in numerous places by trends of thrust-generated folds, regional dips, and gross map patterns of older-onyounger stratigraphic repetition. Most major folds are upright, but a few are overturned in the direction of tectonic transport. Southeast transport is especially evident for the Threemile Creek (TCT) and Snowy Peak (SPT) thrusts of the western Charley River quadrangle, which both have flat lying southeast segments that steepen and root to the northwest. However, east-west fold trends in the underlying Andrew Creek thrust plate (ACT) are oblique to its bounding surfaces, possibly indicating variable directions of thrusting, oblique ramping, or multiple ages of deformation in that area.

On the other hand, south of the Michigan Creek (MCA) and Hard Luck (HLA) anticlines in the southern part of the map area, thrust traces trend predominantly northwest-southeast parallel to structures in the Dawson quadrangle, and the direction of tectonic transport is clearly toward the northeast (see fig. 4 and cross sections $D-D^{\prime}$ and $E-E^{\prime}$, sheet 2).

The remarkable $90^{\circ}-110^{\circ}$ change in orientation of the Charley River fold and thrust belt involves direction of transport as well as structural trend, and takes place along an abrupt "bend" around which individual structures seem to be mappable from one trend to the other. The axis of the "bend" generally coincides with the Michigan Creek (MCA), Hard Luck (HLA), and Harrington Creek (HCA) anticlines. Structures considered to be continuous around the "bend" are (1) the Yukon thrust (YT), (2) the Three Castle Mountain thrust (TCT), (3) the Montauk Bluff (MBT)-Hard Luck (HLT) thrust, and (4) the Fourth of July Creek (FJT)-Seventymile River (SRT) thrust. Correlation of the Fourth of July Creek and Seventymile River thrusts is suggested by their similar structural positions above a distinctive belt of folded and thrusted Tahkandit Limestone and lower 'part of the Glenn Shale that occurs around the flanks of the Michigan Creek anticline.

Modest amounts of tectonic transport, generally of 5 $\mathrm{km}$ or less, are interpreted from cross-section relations for most individual thrust plates. Total shortening distributed within some thrust complexes, such as the Hard Luck duplex (HLD) and Nation River thrust system (NRT), and along the Fourth of July Creek thrust (FJT), may be $10 \mathrm{~km}$ or more. Transport on the Three Castle Mountain thrust (TCT) is also estimated from cross section $D-D^{\prime}$ (sheet 2 ) to be on the order of $10 \mathrm{~km}$, but may be much less in cross section $E-E^{\prime}$. In cross sections $B-B^{\prime}$ and $C-C^{\prime}$, transport on the Three Castle Mountain (TCT) and Cathedral Creek (CCT) thrusts may be comparably large, but displacements cannot be estimated because unlike stratigraphic sequences are juxtaposed that provide no common hanging wall and footwall tie points. Considerable variation in stratigraphic throw is evident on the Yukon thrust (YT) in the Ogilvie River quadrangle and its continuation in the Charley River map area (fig. 4, sheet 2). At least $5,000 \mathrm{~m}$ of stratigraphic throw and an unknown but unquestionably much greater amount of tectonic transport are required along the segment of the Yukon thrust in the Ogilvie River quadrangle, where Late Proterozoic and Cambrian(?) rocks of the Tindir Group override rocks at least as young as Early Cretaceous, whereas no more than $2 \mathrm{~km}$ of displacement is indicated on the segment of the Yukon thrust in the Charley River quadrangle (cross sections $B-B^{\prime}, D-D^{\prime}$, and $E-E^{\prime}$, sheet 2). This variation might arise from the transfer of most Yukon thrust motion to structurally higher splays like the Three Castle Mountain thrust in the Charley River map area. Alternatively, displacement on the Yukon thrust may die out to the south and southeast, or my interpretation of the southward continuation of the Yukon thrust may be in error. Because of lack of subsurface data, the lengths of buiried bedding-parallel segments of various thrust systems are unknown, but the lengths shown in the structure sections based on geometric considerations are thought to be conservative. With this and other uncertainties already mentioned in mind, I tentatively estimate minimum cumulative shortening for all thrusts, down to and including the Yukon thrust, to be on the order of $50 \mathrm{~km}$ for the part of the fold and thrust belt represented on cross sections $B-B^{\prime}$ and $C-C^{\prime}$. Perhaps twice that amount of total cumulative shortening might be accommodated within the fold and thrust belt across the entire Charley River 1:250,000 quadrangle, from the Yukon thrust on the east to the west edge of the quadrangle (Dover and Miyaoka, 1988). More accurate estimates of shortening will require more precise data.

\section{POST-THRUSTING LISTRIC NORMAL FAULTING}

Numerous listric normal faults are shown on the geologic map (sheet 1). These generally involve the Lower Cretaceous Kandik Group and Upper Cretaceous and Tertiary sedimentary rocks, but in places the listric faults involve older rocks as well. Listric normal faults are interpreted from map relations such as (1) steep youngeron-older structural discordances that merge with mapped low-angle thrust faults, (2) pronounced topographic lineaments representing steep- to moderate-dipping fault systems that commonly define half-grabens, or where combined with antithetic normal faults, form grabens, and (3) rock sequences that dip at low to moderate angles into bounding normal faults, presumably because of rotation 
that would require a listric shape at depth. The three best developed areas of listric normal faulting are the Nation River (NRLS) and Kandik River (KRLS) listric fault systems (fig. 4, sheet 2), and along the Tintina fault zone in the southern part of the Charley River A-2 quadrangle. Listric fault relations are best illustrated in the western parts of all cross sections except $E-E^{\prime}$ (sheet 2). Listric faults are typically interpreted to splay from relatively steep-dipping segments of thrust faults, where the thrusts are inferred to ramp up section. As a corollary, ramps were suspected in cross-section construction below areas of abundant listric normal faulting.

\section{TIMING OF FOLD- AND THRUST- BELT DEFORMATION}

There is no positive evidence to suggest compressional deformation prior to the Early Cretaceous in the Charley River fold and thrust belt, but neither can that possibility be eliminated. At least the latest, and probably the main stage of fold- and thrust-belt development occurred after deposition of the Albian Kathul Graywacke and before unconformable deposition of unit TKs of Brabb and Churkin (1969) in mid-Campanian or younger time. The same age of deformation is indicated for all parts of the Charley River fold and thrust belt, regardless of structural trend and direction of thrust transport.

Lower Cretaceous rocks are involved in folding and thrusting throughout the Charley River and surrounding areas. Among the best examples are (1) folds and thrusts involving the Kandik Group, (2) involvement of the Kandik Group in the thrust-generated Step Mountain anticline (SMA), (3) Paleozoic-on-Lower Cretaceous thrust relations in the western Charley River quadrangle, (4) the thrust in the upper Nation River-Jungle Creek area that overrides the Kathul(?) Graywacke, (5) rocks now assigned an Early Cretaceous age in the southeastern Charley River A-3 quadrangle that participated in folding within the Seventymile fold belt (SFB) of the Eagle D-1 quadrangle, and (6) the overriding of rocks now dated as Early Cretaceous beneath the Yukon thrust in the Ogilvie River quadrangle. The Kathul Graywacke or correlative rocks as young as Albian are involved in examples (1), (4), and (5).

There is no demonstrable instance where Upper Cretaceous rocks are involved in folding or thrusting. In the two places where previous mapping suggested that possibility-the southern belt of unit TKs of Brabb and Churkin (1969), and where Norris (1982) assigned rocks below the Yukon thrust in the Ogilvie River quadrangle to the Monster Formation (fig. 4, sheet 2), new evidence for an Early Cretaceous age of the deformed rocks exists (Cushing and others, 1986; see stratigraphic discussion to follow). Additional evidence for a pre-unit TKs age of folding and thrusting is that the Upper Cretaceous and Tertiary sequence lies in angular unconformity across foldand thrust-belt structures at two places, one in the upper Fourth of July Creek, Crowley Creek, and Michigan Creek areas in the Charley River A-2 quadrangle, and the other east of the confluence of Hard Luck Creek and the Nation River, in the southern B-2 quadrangle. The part of the Late Cretaceous represented by unit TKs unit is not well established. However, the consistent association with lower Tertiary strata suggests that the later part of the Late Cretaceous may be represented. A mid-Campanian to mid-Paleocene age is also indicated by the pollen assemblage Aquilapollenites-Wodehousia found at a locality along Washington Creek in the southern belt of unit TKs (Miyaoka, 1990, fossil locality 153; D.J. Nichols, oral commun., 1986).

Listric normal faulting involving Upper Cretaceous and Tertiary strata as young as Eocene(?) post-dates compressional deformation.

\section{PROBLEM AREAS}

Although in most places, reasonable explanations of surface map features can be easily interpreted in terms of typical fold- and thrust-belt structural styles and geometry, a few areas involve more complex interpretations that deviate locally from strict geometric rules of the fold- and thrust-belt model. In some cases, these are places where surface control is relatively poor, so that alternative interpretations would be possible. Generally, however, my preferred interpretations of the problem areas, as illustrated in the cross sections, are based on the projection of pertinent map relations into the line of structure section from adjacent areas. Some cases in point are:

(1) the Hard Luck duplex (HLD), where the floor thrust is shown to truncate a fold in the footwall rather than cut uniformly up section. This interpretation gains support from map relations between Hard Luck and Waterfall Creeks, where previously folded footwall rocks of the Tindir Group are indeed truncated by the floor thrust of the duplex.

(2) the Kandik detachment $(\mathrm{KD})$ and its relation to the Nation River thrust system (NRT). Although the Kandik detachment is mapped as a younger-on-older listric normal fault that merges in the subsurface with gently dipping segments of the Nation River thrust system (cross sections $A-A^{\prime}$ and $B-B^{\prime}$, sheet 1 ), an alternative interpretation involving younger-on-older thrusting-perhaps in the roof zone of a duplex, was considered but could not be modeled satisfactorily in structure sections. The nature of the Kandik detachment should be re-evaluated when more precise map control is available.

(3) places where thrust faults are interpreted to emplace younger-on-older rocks, such as (a) along the Hard Luck thrust (HLT) in section $A-A^{\prime}$, (b) along some thrusts involving the Kandik Group in the western parts of sections $A-A^{\prime}$ and $B-B^{\prime},(c)$ in some horses of the Hard Luck duplex (HLD), and (d) along the Pass Creek thrust (PCT) in the subsurface and on some of its splays in section $D-D^{\prime}$. Possible explanations for these anomalies are varied. For (a) and (c), complicated surface map relations ensure that any structural interpretation of the Hard Luck duplex will be complex. Imprecise mapping and lack of subsurface control limit the ability to adequately understand its geometry. However, anomalous youngeron-older thrusting within some horses may be explained by local map patterns suggesting that some horse-bounding faults cut diagonally across tight folds. Regarding (b), bedding-parallel thrusting rather than low-angle listric 
normal faulting is suggested by the apparent thickening of units like the upper part of the Glenn Shale in section $B-B^{\prime}$ and the Kathul Graywacke in section $A-A^{\prime}$, which is accommodated by folding and blind thrusting. However, thickness variations within these units are poorly constrained and other interpretations are possible. And for (d), I suspect that Pass Creek thrusting involves a decollement at the base of the Lower Cambrian Funnel Creek Limestone, but that interpretation is poorly constrained at depth.

(4) the folded detachment within the Fourth of July Creek (FJT)-Waterfall Creek (WCT) thrust plate, between the Yukon River and Hard Luck Creek (best seen on section line $\left.C-C^{\prime}\right)$. Anticlinal folding of this discontinuity along with the overlying Paleozoic section and the structurally overriding Nation Reef thrust plate (NFT) may have occurred as a result of movement of the Fourth of July Creek-Waterfall Creek thrust over a buried ramp. The nature of the detachment is questionable.

\section{STRATIGRAPHIC PROBLEMS BEARING ON STRUCTURAL INTERPRETATION}

Although a comprehensive stratigraphic discussion is not an objective of this report, field observations and structural reinterpretation raise some stratigraphic questions that deserve mention and merit further study. Among these questions are (1) the problem of facies variations and correlation within the Late Proterozoic and Lower Cambrian(?) upper part of the Tindir Group, (2) the age and stratigraphic assignment of Oldhamia-bearing beds, (3) the degree to which abrupt, locally developed unconformities may be controlled by pre-thrusting highangle faults, (4) the problem and structural significance of distinguishing between chert-pebble conglomerates of at least three distinct ages, and (5) the degree to which some structural discontinuities are controlled by major unconformities.

\section{FACIES CHANGES AND CORRELATION WITHIN THE UPPER PART OF THE TINDIR GROUP}

It was impossible to trace some individual units of the Tindir Group described by Brabb and Churkin (1969) and Young (1982) through the map area, especially those in the upper part of the Tindir. This is not surprising in view of the local facies changes described by Young in the sections he examined in detail. Significant differences in stratigraphic sequence occur from one thrust plate to another as well as along strike within individual plates, but the variations were not studied systematically enough to warrant detailed discussion here. However, the number of informal units of local extent used on this geologic map (sheet 1 ) is a consequence of the facies variations encountered, and the range of variation is indicated by the differences in lithic content of these units. The differences are mainly in relative proportions of component lithologies-especially between carbonate and quartziteargillite components, but also in the amount of interfingering chert-clast conglomerate, diamictite, red beds, and basaltic volcanic rocks (figs. 2 and 3 , sheet 1 ).
For example, for strata in the uppermost part of the Tindir lying above the prominent basalt and red beds marker unit, the dolomitic sandstone and shale (ss) and limestone (Is) units of Brabb and Churkin (1969) are not representative of the equivalent part of the Tindir described by Young (1982) in the Tatonduk thrust plate (TT) nor of the sections seen during this study in the Three Castle Mountain (TCT) and Fourth of July Creek (FJT)-Waterfall Creek (WCT) thrust plates, where quartz-rich arenites predominate. Unit $€ Z \mathrm{tlq}$, which contains interlayered quartzite and limestone, may represent an interfingering facies transitional between dominantly clastic and dominantly carbonate sequences, but my mapping was not sufficiently detailed to demonstrate the map continuity of the suspected facies transitions.

Where the map continuity of intergradational facies relations cannot be demonstrated, as between different thrust plates, the possibility of unrecognized structural duplication complicates stratigraphic correlation. A case in point is the basalt and sedimentary rocks of Washington Creek (€Ztbs), which occurs on trend with the Tindir in the Fourth of July Creek (FJT) and Logan Creek (LCT) thrust plates, but which contains much more tuffaceous and dark argillaceous material than the somewhat similar basalt and red beds unit of the Tindir (Brabb and Churkin, unpublished field notes). Also, chemical analyses of Washington Creek basalts differ in some minor element abundances from typical Tindir basalts (Brabb and Hamachi, 1977; Young, 1982). On the other hand, some minor lithologies of the Washington Creek unit, such as basaltic agglomerate, chert-clast conglomerate, and black platy limestone, also occur in the upper part of the Tindir. Without stronger evidence to the contrary, we tentatively follow Brabb and Churkin in regarding the Washington Creek unit as a facies of the basalt and red beds unit of the upper part of the Tindir. However, the most likely alternative would be that the Washington Creek unit represents interfingering of the Devonian Woodchopper Volcanics and Nation River Formation in a separate thrust plate.

\section{AGE AND STRATIGRAPHIC ASSIGNMENT OF OLDHAMIA-BEARING BEDS}

There are 10 occurrences of the trace fossil Oldhamia known within the southeastern Charley River map area (Miyaoka, 1990). All 10 fossil localities are north of the Yukon River, in the Nation River (NRT), Fourth of July Creek (FJT)-Waterfall Creek (WCT), and Montauk Bluff (MBT) thrust plates. Of these, four are in rocks tentatively assigned to the Lower Cambrian Adams Argillite. The principal lithology containing Oldhamia is tan to olive-green, rusty-weathering, thinly laminated, sericitic siltite and argillite containing thin, yellow-brown, locally cross-laminated quartzite interbeds. The assignment to the Adams is supported by the presence of overlying and underlying limestone beds resembling the Hillard and Funnel Creek Limestones, respectively, but which are not dated locally. All the dating of the Hillard has been in structurally lower thrust plates (Brabb, 1967; Churkin and Brabb, 1965b); the 
Funnel Creek is not fossiliferous. The other six occurrences of Oldhamia are in lithologically similar silty beds that I tentatively assign to my red beds and quartzite unit (€Ptrq) of the upper part of the Tindir Group. This assignment was made because (1) bracketing Lower Cambrian limestones are apparently absent, (2) silty and argillaceous strata are unusually thick compared with typical thicknesses of the Adams, and (3) similar finegrained clastic rocks occur within what is unequivocally the upper part of the Tindir in places. In particular, an Oldhamia locality east of Nation River, about $6 \mathrm{~km}$ above its mouth, is in argillite below a medium- to dark-gray, platy, stylolitic limestone that more closely resembles limestones in the upper part of the Tindir than it does the Hillard (Miyaoka, 1990, locality 345).

Churkin and Brabb (1965b) favored an Early Cambrian age for Oldhamia in east-central Alaska, based on the correlation of argillaceous Oldhamia beds with the Adams Argillite. If the assignment herein of some Oldhamia beds to the Tindir is correct, either the uppermost part of the Tindir, as mapped, is Early Cambrian in age, as previously indicated by Kline (1977), Payne and Allison (1978), and Allison (in press), or the age range of Oldhamia extends into the latest Proterozoic. However, alternatives to this assignment to the upper part of the Tindir (€Ztrq) are possible for some of the Oldhamia occurrences. In the Nation River thrust system (NRT) localities, for example, where the Permian Tahkandit Limestone rests unconformably on the Oldhamia beds, an alternative assignment of the Oldhamia beds to the Adams Argillite is possible if the absence of the Hillard is attributed to erosion beneath the Permian section, and the absence of the Funnel Creek Limestone is attributed to insufficient depth of exposure or structural truncation at the base of the Nation River thrust system. If so, possible explanations for the unusually great thickness of these Oldhamia beds are structural thickening, or structural introduction of a thicker facies of the Adams Argillite.

The problem of the age and stratigraphic assignment of Oldhamia-bearing beds is unresolved. Until it is, an Early Cambrian age and assignment to the Adams Argillite should not be assumed for Oldhamia occurrences in the southeast Charley River quadrangle.

\section{UNCONFORMITIES CONTROLLED BY PRE- THRUSTING HIGH-ANGLE FAULTS}

The Permian Tahkandit Limestone and Step Conglomerate unconformably overlie Devonian and Mississippian rocks across most of the southeastern Charley River map area. However, within the lower slices of the Nation River thrust system (NRT), Permian limestone appears to lie in angular unconformity directly on Early Cambrian or older Oldhamia-bearing beds. The Devonian Nation River Formation and McCann Hill Chert appear to thin abruptly over a distance of $2 \mathrm{~km}$ or less toward the area where they are absent completely. Thickness changes in lower Paleozoic units missing beneath the angular unconformity cannot be observed, but they must have been abrupt because these units are fully developed in the structurally underlying Waterfall Creek
(WCT) thrust plate, and apparently in upper slices of the Nation River thrust system as well. The limited extent of the angular unconformity and the apparent abruptness of the thickness variations associated with it suggest a faultbounded block uplift. This interpretation is illustrated in cross sections $B-B^{\prime}$ and $C-C^{\prime}$ (sheet 2), and on the schematic reconstruction illustrating stratigraphic relations interpreted from restored thrust plates (fig. 2 , sheet 1 ). It is not certain how much thinning was produced by prePermian erosion as opposed to penecontemporaneous non-deposition across an intermittently active Paleozoic high. But the fact that no sedimentological evidence for a nearby uplift has been recognized as yet in the lower and middle Paleozoic rocks closest to the area of the angular unconformity suggests that uplift was active mainly in post-Devonian time, and therefore that most thinning was erosional. A predominantly Permian age of uplift is also suggested by the occurrence nearby, in the same thrust plate, of the thick Permian Step Conglomerate, the dominant chert clasts of which may have been derived directly from cherty Paleozoic rocks eroded from such an uplift, or from reworked chert clasts of the. Nation River Formation as it was eroded.

\section{PROBLEM AND SIGNIFICANCE OF DISTINGUISHING CHERT-CLAST CONGLOMERATES OF AT LEAST THREE DISTINCT AGES}

Chert-clast conglomerates of many ages have been identified in the southeastern Charley River area. The most important of these occur in the Upper Devonian Nation River Formation, the Permian Step Conglomerate, and an Upper Cretaceous and Tertiary unit (TKs) of sandstone, conglomerate, and mudstone. Systematic pebble counts have not been made for these units, but field inspection suggests that all three contain clasts of mainly light- to dark-gray or subordinate green chert, lightcolored quartzite, and white quartz, in order of decreasing abundance, set in a poorly sorted matrix of chert-quartz arenite. The quartzite clasts are more rounded and larger than other clasts, and occur locally as cobbles and boulders as much as $30 \mathrm{~cm}$ across. The Paleozoic conglomerates are also similar to one another in degree of induration, although there is a stronger tendency at exposures tentatively mapped as the Step for the quartzite cobbles and boulders to weather out than at most exposures mapped as the Nation River, but this could reflect a relatively greater abundance of coarse quartzite clasts at the Step localities. The Upper Cretaceous and Tertiary conglomerates are generally much less indurated, and in the outcrop belt along the Tintina fault zone in the southern part of the map area are typically associated with easily eroded, commonly slumped, and generally lightcolored sedimentary rocks. These are characteristics whereby conglomerates of unit TKs can usually be distinguished from Paleozoic ones. However, in places, principally in the southern part of the Charley River A-2 quadrangle (and the adjacent Eagle D-1 quadrangle), conglomerates assigned to unit TKs by Brabb and Churkin $(1965,1969)$ are well indurated, form resistant uplands, and lack associated light-colored sedimentary rocks. 
Dating of the conglomerates is difficult and sparse. Late Devonian spores were recovered from argillaceous interbeds of the Nation River Formation in a few localities by Brabb and Churkin (1967). Limestone interbeds in the Step Conglomerate yield Permian shelly faunas resembling those of the Tahkandit Limestone (Brabb, 1969) and reworked Late Devonian and Mississippian conodont faunas (Kirk Denkler and Anita Harris, written commun., 1985). The age of the Upper Cretaceous and Tertiary unit is based on pollen and plant remains from carbonaceous shale and siltstone considered to be stratigraphically associated with the conglomeratic beds. Along Washington Creek in the A-3 quadrangle, Late Cretaceous pollen is reported at two localities (Miyaoka, 1990, fossil localities 34 and 153), and Eocene(?) leaves are known from another (Miyaoka, 1990, fossil locality 154). However, Early Cretaceous plants are reported by Jack Wolfe (written commun., 1960) for the more indurated rocks of the same belt of unit TKs in the Eagle D-1 quadrangle, $7 \mathrm{~km}$ southeast of the Charley River quadrangle. Poorly preserved pollen at the same locality is also suggested by Tschudy (1962, written commun.) to represent an Early Cretaceous rather than Late Cretaceous assemblage. Furthermore, these may be the same Lower Cretaceous rocks "in the vicinity of the Seventymile River" suggested by Brabb (1969, p. 125) to correlate with the Kathul Graywacke and on which the Albian age of the Kathul was tentatively based.

Numerous chert clasts within the various conglomerates contain radiolarians, but recovery of identifiable forms with age ranges sufficiently short to be useful has been rare. Where radiolarian chert clasts yield ages, the maximum age indicated for the conglomerate has not always been compatible with the unit as previously mapped. The most important discrepancy lies outside the area of the geologic map (sheet 1), in the Eagle D-1 quadrangle, where conglomerate mapped as the Nation River (Upper Devonian) contains clasts with radiolarians as young as Mississippian (Kitty Reed, written commun., 1986). This is significant to this map because the same belt of conglomerate may extend into the southern Charley River A-2 quadrangle.

Aside from the obvious regional stratigraphic significance of distinguishing between conglomerates of drastically different ages, there are two important structural implications. The first is that uncertainties in identification of key units hinders comparison of stratigraphic sequences between various thrust plates and prevents the balanced restoration of those thrust sequences. The second implication involves structural timing. The Paleozoic conglomerates, as well as rocks as young as Early Cretaceous, are clearly involved in foldand thrust-belt deformation throughout the Charley River quadrangle. As mapped by Brabb and Churkin (1969), the dominantly conglomeratic southern belt of unit TKs in the Charley River A-2 and A-3 quadrangles has low dips and lies in angular unconformity across the trend of (and therefore post-dates) the Fourth of July Creek (FJT) and Logan Creek (LCT) thrust plates and also truncates the Michigan Creek anticline (MCA). However, previous mapping also shows the same belt of unit TKs to occur in the Eagle $\mathrm{D}-1$ quadrangle within a large syncline coincident with the Seventymile fold belt (SFB), which I regard as a fold- and thrust-belt feature. Dips on the conglomerate there are steep to nearly vertical. If correct, these crosscutting relations and map distribution would require two distinct ages of fold- and thrust-belt structures-one pre-dating and the other post-dating the deposition of unit TKs. This is unlikely. The apparent stratigraphic and structural continuity between the Fourth of July Creek, Michigan Creek, and Seventymile Creek areas suggest that the same structural belt with a common age is represented in all three areas (geologic map, sheet 1 , and fig. 4, sheet 2). The ages and stratigraphic relations of rocks included within unit TKs as originally mapped by Brabb and Churkin are critical to the question of structural timing. These relations are poorly understood at present, but the simplest interpretation consistent with the data presently known is that unit TKs contains two conglomeratic sequences, as suggested by Cushing and others (1986) - (1) an older more indurated sequence of Early(?) Cretaceous age that participated in foldand thrust-belt deformation, and (2) a younger, less indurated, and characteristically light-colored sequence of Late Cretaceous and Tertiary age that unconformably overlies sequence (1) and post-dates thrusting. The suspected unconformity between the two sequences is poorly constrained and only approximately located on the geologic map (sheet 1); it needs to be evaluated by more detailed mapping. Moreover, some problems may still exist in distinguishing well-indurated Lower Cretaceous conglomerates of sequence (1) from Paleozoic conglomerates.

\section{CONTROL OF STRUCTURAL DISCONTINUITIES BY MAJOR UNCONFORMITIES}

There are two notable instances in the southeastern Charley River quadrangle where structural discontinuities are suspected to be controlled by major unconformities. One is along the Cathedral Creek thrust (CCT) between the upper and lower parts of the Tindir Group, as subdivided informally in this report. In the upper Cathedral Creek and Waterfall Creek areas, the Cathedral Creek thrust cuts up section and occupies the unconformity below the Cambrian and Ordovician Jones Ridge Limestone.

The other example is the Kăndik detachment $(\mathrm{KD})$, which follows an unconformity interpreted to separate the Glenn Shale as originally defined (Brabb, 1969) into a lower part of Triassic limestone and shale, and an upper part of Jurassic(?) and Lower Cretaceous carbonaceous shale and minor quartzite (Churkin and others, 1982). This unconformity needs further evaluation, but the Triassic part of the Glenn is generally in depositional sequence on the Permian Tahkandit Limestone, whereas the base of the upper part of the Glenn is structurally detached from its substrate in most places. Locally however, as at Step Mountain, the upper part of the Glenn appears to lie depositionally on a variety of preCretaceous units. 


\section{REGIONAL TECTONIC RELATIONS AND IMPLICATIONS}

\section{REGIONAL EVIDENCE FOR RECURRENT HIGH- ANGLE FAULT-CONTROLLED BLOCK UPLIFTS PRIOR TO THRUSTING}

Stratigraphic evidence for pre-thrusting, probably fault-controlled uplifts of Permian (and older?) age was cited for the Nation River thrust system in an earlier section of this report. The evidence is mainly in the abruptness and local extent of erosion below the unconformable Permian Tahkandit Limestone and in the corresponding local development of a thick section of the Permian Step Conglomerate nearby. Similarly abrupt facies variations already described within the upper part of the Tindir Group also suggest differential fault-block movements in Late Proterozoic or earliest Cambrian time. Although no Proterozoic faults have been identified in the southeastern Charley River area, graben-bounding faults with pre-Early Cambrian movement are recognized in the Ogilvie Mountains of the Dawson 1:250,000 quadrangle by Thompson and Eisbacher (1984), who attribute them to a widespread episode of crustal extension and thinning in the outer part of the ancient Cordilleran continental margin. Facies relations in the upper part of the Tindir are compatible with that interpretation. Local faultbounded block uplifts may also be the source for chertand quartzite-rich conglomerates in the Devonian Nation River Formation, as is suspected for lithologically similar clastic rocks of the Devonian and Mississippian Earn Group of southern Yukon Territory (Gordey, 1985; Gordey and Orchard, 1985).

\section{REGIONAL EXTENT AND ORIGIN OF THE ABRUPT CHANGE IN CHARLEY RIVER FOLD- AND THRUST- BELT ORIENTATION}

The striking change of $90^{\circ}-110^{\circ}$ in the orientation of the Charley River fold and thrust belt as documented within the southeastern Charley River map area can be seen from the tectonic map (fig. 4, sheet 2) to be a change of regional extent and significance. Structures with consistent northwest-southeast trends and predominantly northeast transport directions that are representative of the northern Cordilleran fold and thrust belt throughout southern Yukon Territory project into the southeastern Charley River map area from the Dawson and northeastern Eagle 1:250,000 quadrangles. Some license was taken in connecting individual thrusts across these quadrangles because of the preliminary status of some mapping there, but there is little question as to the trend and polarity of the structures involved. In contrast, structures in the rest of the Charley River quadrangle have predominantly southeast transport directions and track northeast to north-northeast through the Ogilvie River quadrangle and into northern Yukon Territory. Map continuity and correlation of individual structures between the Charley River and Ogilvie River quadrangles is excellent. The axis of the change in structural orientation projects eastward from the southeastern Charley River map area into a narrow zone separating belts of east-west and north-northeast structural trends north of the Monster syncline in the Ogilvie River quadrangle (fig. 4, sheet 2).

The origin of the abrupt change in orientation of the Charley River fold and thrust belt and the mechanism by which it occurs are uncertain. Assuming that the northeast trending fold and thrust belt of northern Yukon Territory is an extension of the northern Cordilleran fold and thrust belt, and that the two belts are continuous and directly connected through the Charley River area as my map interpretation suggests, three alternative explanations for their differences in orientation have been considered.

(1) They may represent the original configuration of the continental margin at the time the orogen formed. This seems unlikely because it is difficult to visualize a convergent mechanism whereby identical styles and magnitudes of structural shortening could be produced simultaneously along segments of a continental margin having such different orientations with respect to the direction of convergence. Relatively direct convergence along one segment of the orogen would seem to require more oblique convergence with recognizably different deformational effects along another segment with drastically different orientation.

(2) Two intersecting deformational belts of different ages may be present. This alternative seems unlikely in view of the continuity of structures from one trend to the other - especially the apparent bending of the folded and thrusted belt consisting of the Tahkandit Limestone and the lower part of the Glenn Shale around the flanks of the Michigan Creek Anticline, and the lack of evidence for different ages of deformation for the differently oriented segments of the fold and thrust belt.

(3) An originally straighter orogen with northwesttrend and northeast-directed thrusting may have undergone at least $90^{\circ}$ of dextral oroclinal bending. The main problem with this possibility is the apparent lack of evidence for intense post-thrusting compression which is to be expected within the core of a major oroclinal bend. No significant differences in the density or intensity of compressional structures along the axis of the possible orocline are evident, but the degree to which pre-existing structures may be tightened-up is more difficult to evaluate. Also, the role that strike-slip movement, generated locally within the core of an orocline, might play in its development is uncertain.

\section{THE TINTINA FAULT ZONE-RELATION TO THE CHARLEY RIVER FOLD AND THRUST BELT, AND TIMING}

Fold- and thrust-belt structures are truncated and offset by the Tintina fault zone in the southeastern Charley River, northeastern Eagle, and Dawson quadrangles (fig. 4, sheet 2). The fold and thrust belt north of the Tintina fault zone is juxtaposed with metamorphic and igneous complexes of the Yukon-Tanana upland to the south, the origins and original location of which are currently under debate (Foster and others, in press; Mortensen and Jilson, 1985; Dusel-Bacon and Aleinikoff, 1985; Erdmer, 1985; Tempelman-Kluit, 1979). The identification and location of the displaced segment of the fold and thrust belt south 
of the Tintina fault are also under study but have been suggested by Tempelman-Kluit (1984) and Dover (1985b) to be in the Livengood area, a few hundred kilometers to the west. About $450 \mathrm{~km}$ of right-lateral displacement of major geotectonic subdivisions of the northern Canadian Cordillera seems well-documented in southern Yukon Territory (Gordey, 1981) and is comparable to displacements estimated for the Alaskan part of the Tintina zone by Dover (1985b).

The main Tintina fault zone is largely covered by the belt of Upper Cretaceous and Tertiary sedimentary rocks (TKs) in the southern part of the southeastern Charley River map area. Faults cutting unit. TKs appear to have only modest dip-slip displacements and some are interpreted from their curvilinear shapes to be listric normal faults. To the west, in the Circle 1:250,000 quadrangle, minor dip-slip movement continues along a few faults with modern scarps that cut deposits as young as Pleistocene (Foster and others, 1983). Although some tens of kilometers of Late Tertiary and (or) younger right slip has been interpreted for the Tintina fault system from the distribution of placer gold deposits and possibly offset stream drainages (Barker, 1986), at least $400 \mathrm{~km}$ of the total strike separation estimated for the Tintina system in the Charley River quadrangle appears to have occurred in the short span between the time that fold- and thrust-belt deformation ceased and unconformable deposition of unit TKs began. The maximum time interval that would appear to be available for both fold- and thrust-belt development and the main Tintina strike-slip event is on the order of 25 million years, assuming that Albian deposition ceased and compressional orogeny began about $100 \mathrm{Ma}$, and that the deposition of unit TKs began no earlier than about $75 \mathrm{Ma}$ in mid-Campanian time. These estimates are compatible with preliminary time constraints known from the southeastern Charley River quadrangle and adjacent areas. If correct, they leave little choice in partitioning compressive orogenic and strike-slip movements within this narrow time interval. Assuming a conservative slip rate of $4.0 \mathrm{~cm} / \mathrm{yr}$, it would take ten million years to produce the $400 \mathrm{~km}$ of pre-Tertiary rightslip estimated for the Tintina fault zone-and would occupy the interval from 85-75 Ma. This would restrict the time available for the main phase of compressional fold- and thrust-belt development to the 15 million year interval from 100-85 Ma. Earlier compressional deformation, which is documented elsewhere in the Cordilleran orogen (Price, 1980) but for which there is no local evidence, is not considered in this model. If, as suggested here, the compressional and strike-slip events were distinctly separated in time and both were driven by lithospheric plate interactions, a fundamental change in plate motions-perhaps from direct to more oblique convergence, would be required at about $85 \mathrm{Ma}$ to account for the dramatic change in deformational styles and response in this part of the northern Cordillera. Doubling the rate of Tintina right slip to a still reasonable $8 \mathrm{~cm} / \mathrm{yr}$ decreases the time required for $400 \mathrm{~km}$ of Tintina slip to five million years, increases the time available for compressional deformation to 20 million years, and places the hypothetical change in plate motions at about $80 \mathrm{Ma}$.

There is no convincing evidence known to me for transpressional interaction between the Charley River fold and thrust belt and the Tintina strike-slip system in the east-central Alaska region that would allow any relaxation of the rigid time constraints suggested above.

\section{ACKNOWLEDGMENTS}

I wish to thank Mike Churkin and Earl Brabb for their encouragement and cooperation in all phases of this study, and for the outstanding job they did in archiving their field notes and field sheets, without which this structural re-evaluation could not have been made. Mike Churkin's willingness to review his field data and discuss east-central Alaskan geologic problems with me are particularly appreciated. Ellen White and Sue Wood, formerly of the U.S. Geological Survey's Technical Data Unit in Menlo Park, were especially helpful and always successful in finding the archival data I needed. I am also indebted to Bob Thompson and Steve Gordey, of the Geological Survey of Canada, who generously arranged field tours of their map areas in Yukon Territory that provided indispensible regional geologic perspective applicable to Alaskan problems.

\section{REFERENCES CITED}

Allison, C. W., in press, Paleontology of Late Proterozoic and Early Cambrian rocks of east-central Alaska: U.S. Geological Survey Professional Paper 1449.

Barker, J. C., 1986, Placer fold deposits of the Eagle Trough, upper Yukon River region, Alaska, U.S. Bureau of Mines Information Circular IC-9123, 20 p.

Brabb, Earl E., 1967, Stratigraphy of the Cambrian and Ordovician rocks of east-central Alaska: U.S. Geological Survey Professional Paper 559-A, 30 p.

, 1969, Six new Paleozoic and Mesozoic formations in east-central Alaska: U.S. Geological Survey Bulletin 1274-I, $26 \mathrm{p}$.

Brabb, Earl E., and Churkin, Michael, Jr., 1965, Preliminary geologic map of the Eagle D-l quadrangle, east-central Alaska: U.S. Geological Survey Open-File Report 249 (65-20), 2 sheets, scale 1:63,360.

- 1967 , Stratigraphic evidence for the Late Devonian age of the Nation River Formation, eastcentral Alaska, in Geological Survey Research 1967: U.S. Geological Survey Professional Paper 575-D, p. D4-D15.

- 1969, Geologic map of the Charley River quadrangle, east-central Alaska: U.S. Geological Survey Miscellaneous Geologic Investigations Map I-573, scale 1:250,000.

Brabb, Earl E., and Hamachi, Bette R., 1977, Chemical composition of Precambrian, Paleozoic, Mesozoic and Tertiary rocks from east-central Alaska: U.S. Geological Survey Open-File Report 77-631, 166 p.

Brooks, A. H., and Kindle, E. M., 1908, Paleozoic and associated rocks of the upper Yukon, Alaska: Geological Society of America Bulletin v. 19, p. 225-314. 
Cairnes, D. D., 1914, The Yukon-Alaska international boundary between Porcupine and Yukon Rivers: Geological Survey of Canada Memoir 67.

Churkin, Michael, Jr., and Brabb, Earl E., 1965a, Ordovician, Silurian, and Devonian biostratigraphy of east-central Alaska: American Association of Petroleum Geologists Bulletin v. 49, no: 2, p. 172-185.

__ 1965b, Occurrence and stratigraphic significance of Oldhamia, a Cambrian trace fossil, in east-central Alaska, in Geological Survey Research 1965: U.S. Geological Survey Professional Paper 525-D, p. D120-D124.

Churkin, M., Jr., Foster, H. L., Chapman, R. M., and Weber, F.R., 1982, Terranes and suture zones in eastcentral Alaska: Journal of Geophysical Research v. 87 , no. B5, p. 3718-3730.

Clough, James G., and Blodgett, Robert B., 1984, Lower Devonian basin to shelf carbonates in outcrop from the western Ogilvie Mountains, Alaska and Yukon Territory: Canadian Society of Petroleum Geologists 1984 Core Conference on Carbonates in Subsurface and Outcrop (Calgary, Alberta), p. 57-79.

Cushing, Grant W., Meisling, Kristian E., Christopher, Ray A., and Carr, Tim R., 1986, The Cretaceous to Te:tiary evolution of the Tintina fault zone, eastcentral Alaska [abs.]: Geological Society of America Abstracts with Programs v. 18, no. 2, p. 98.

Dahlstrom, Clinton D. A., 1970, Structural geology in the eastern margin of the Canadian Rocky. Mountains: Bulletin of Canadian Petroleum Geology v. 18, no. 3, p. 332-406.

Dover, J. H., 1985a, Possible oroclinal bend in Northern Cordilleran fold and thrust belt, east-central Alaska [abs.]: Geological Society of America Abstracts with Programs v. 17 , no. 6 , p. 352.

- 1985b, Dispersion of Tintina fault displacement in interior Alaska [abs.]: Geological Society of America Abstracts with Programs v. 17, no. 6, p 352.

Dover, J. H., and Miyaoka, R. T.,1988, Preliminary geologic map and fossil data, Charley River quadrangle, east-central Alaska: U.S. Geological Survey Miscellaneous Field Studies Map MF-2004, 13 p., scale 1:250,000.

Dusel-Bacon, Cynthia, and Aleinikoff, John N., 1985 , Petrology and tectonic significance of augen gneiss from a belt of Mississippian granitoids in the YukonTanana terrane, east-central Alaska: Geological Society of America Bulletin v: 96, no. 4, p. 411-425.

Erdmer, P., 1985, An examination of the cataclastic fabric and structures of parts of Nisutlin, Anvil and Simpson allochthons, central Yukon-a test of the arc-continent collision model: Journal of Structural Geology v. 7, p. 57-72.

Foster, Helen L., 1976, Geologic map of the Eagle quadrangle, Alaska: U.S. Geological Survey Miscellaneous Geologic Investigations Map I-922, scale 1:250,000.

Foster, Helen L., Keith, Terry E. C., and Menzie, W. David, in press, East-central Alaska, in Plafker,
George, and Jones, D .L., eds., The Cordilleran orogen--Alaska: Geological Society of America DNAG v. $\mathrm{G}-1$

Foster, Helen L., Laird, Jo, Keith, Terry E. C., Cushing, Grant W., and Menzie, W. D., 1983, Preliminary geologic map of the Circle quadrangle, Alaska: U.S. Geological Survey Open-File Report 83-170A, 30 p., scale 1:250,000.

Gardner, M. C., Jarrard, R. D., and Mount, V., 1984, Style and origin of structures, Paleozoic and Precambrian sedimentary rocks of southern Tatonduk terrane, Alaska [abs.]: Geological Society of America Abstracts with Programs v. 16, no. 5, p. 285.

Gordey, Steven P., 1981, Stratigraphy, structure and téctonic evolution of southern Pelly Mountains, in the Indigo Lake area, Yukon Territory: Geological Survey of Canada Bulletin 318, 44 p.

_. 1985, Devono-Mississippian sedimentation and tectonism in the Canadian Cordilleran miogeocline [abs.]: Geological Society of America Abstracts with Programs v. 17, no. 6, p. 357.

Gordey, Steven P., and Orchard, Michael J., 1985, Stratigraphic evolution and conodont dating of the outer Cordilleran miogeocline, Yukon and NWT [abs.]: Geological Society of America Abstracts with Programs v. 17 , no. 6 , p. 357.

Green, L.H., and Roddick, J. A., 1961, Geology of the Dawson map area, Yukon Territory: Geological Survey of Canada Map 1284A, scale 1:250,000.

Jones, D. L., Silberling, N. J., Coney, P. J., and Plafker, George, 1984, Lithotectonic terrane map of Alaska, in Silberling, N. J., and Jones, D. L., eds., Lithotectonic terrane maps of the North American Cordillera: U.S. Geological Survey Open-File Report 84-523, 12 p., scale 1:2,500,000.

Kindle, E. M., 1908, Geologic reconnaissance of the Porcupine Valley, Alaska: Geological Society of America Bulletin v. 19, p. 515-328.

Kline, Gary, 1977, Earliest Cambrian (Tommotian) age of the-Upper Tindir Group, east-central Alaska [abs.]: Geological Society of America Abstracts with Programs v. 9, no. 4, p. 448.

Laudon, Lowell R., Hartwig, A. E., Morgridge, Dean L., and Omernik, John B., 1966, Middle and Late Paleozoic stratigraphy, Alaska-Yukon border area between Yukon and Porcupine Rivers: American Association of Petroleum Geologists Bulletin v. 50, no. 9 , p. $1868-1889$.

Mertie, J. B., Jr., 1930, Geology of the Eagle-Circle district, Alaska: U.S. Geological Survey Bulletin 816, $168 \mathrm{p}$. , 1932, The Tatonduk-Nation district, Alaska: U.S. Geological Survey Bulletin 836-E, p. 347-454.

- 1937, The Yukon-Tanana region, Alaska: U.S. Geological Survey Bulletin 872, 276 p.

Miyaoka, Ronny T., 1990, Fossil locality map and fossil data for the southeastern Charley River quadrangle, east-central Alaska: U.S. Geological Survey Miscellaneous Field Studies Map MF-2007, scale $1: 100,000$ 
Mortensen, J. K., and Jilson, G. A., 1985, Evolution of the Yukon-Tanana terrane-evidence from southeastern Yukon Territory: Geology v. 13, no. 11, p. 806-10.

Norris, D. K., 1979, Geology of the Ogilvie River map area, Yukon Territory: Geological Survey of Canada Map 1526A, scale 1:250,000.

Payne, Myron W., and Allison, Carol W., 1978, Precambrian-Cambrian sedimentary rocks from eastcentral Alaska [abs.]: American Association of Petroleum Geologists Bulletin v. 62, no. 3, p. 553.

Prindle, L. M., 1905, The gold placers of the Fortymile, Birch Creek, and Fairbanks regions, Alaska: U.S. Geological Survey Bulletin 251, 89 p.

- 1906, The Yukon-Tanana region, Alaskadescription of the Circle quadrangle: U.S. Geological Survey Bulletin 295, $27 \mathrm{p}$.

_- 1913, A geologic reconnaissance of the Circle quadrangle, Alaska: U.S. Geological Survey Bulletin $538,82 \mathrm{p}$.

Price, R. A., 1980, The Cordilleran foreland thrust and fold belt in the southern Canadian Rocky Mountains: Geological Society of London Special Publication no. 9,22 p.

Royse, F., Jr., Warner, M. A., and Reese, D. L., 1975, Thrust belt structural geometry and related stratigraphic problems, Wyoming-Idaho-northern Utah: Rocky Mountain Association of Geologists 1975 Symposium, p. 41-54.

Tempelman-Kluit, D. J., 1979, Transported cataclasite, ophiolite, and granodiorite in Yukon-evidence of arccontinental collision: Geological Survey of Canada Paper 79-14, $27 \mathrm{p}$.

- 1984, Counterparts of Alaska's terranes in Yukon: Geological Association of Canada SymposiumCordilleran geology and mineral exploration, status and future trends (Vancouver), p. 41-44.

Thompson, Bob, and Eisbacher, Geri H., 1984, Late Proterozoic rift assemblages, northern Canadian Cordillera [abs.]: Geological Society of America Abstracts with Programs v. 16, no. 5, p. 336.

Young, Grant, M., 1982, The Late Proterozoic Tindir Group, east-central Alaska-evolution of a continental margin: Geological Society of America Bulletin v. 93, no. 8, p. 759-783.

\section{DESCRIPTION OF MAP UNITS}

\section{QUATERNARY SURFICIAL DEPOSITS}

Qa Alluvium (Holocene)-Crudely stratified silt, sand, and gravel deposited by present streams as channel fill or flood-plain materials; also includes swamp and ironrich bog deposits, and locally, alluvial fan and deltaic deposits

Qt Terrace deposits (Holocene and Pleistocene)-Crudely stratified and poorly sorted gravel, sand, and silt, in terraces standing as much as $150 \mathrm{~m}$ above present stream bed
Loess(?) (Pleistocene)-Wind-blown sand and silt interpreted to mantle topographic benches along tributary stream divides south of Yùkon River, at elevation 450-670 m; may also include alluvium, colluvium, or other materials

\section{TERTIARY AND CRETACEOUS SEDIMENTARY ROCKS}

Sandstone, conglomerate, and mudstone (lower Tertiary and Upper Cretaceous)-Poorly sorted, poorly consolidated, buff-colored sandstone, grit, and pebble- to cobbleconglomerate, with subordinate dark-gray to black carbonaceous mudstone containing lignitic coal seams a few centimeters or less thick. Clasts well rounded and consist primarily of quartzite and chert, but other locally derived clasts present in places. Reported by Brabb (unpublished field notes) to lie in angular unconformity on Nation River Formation (Upper Devonian) along Nation River. Pollen and poorly preserved flora indicate a latest Cretaceous to Eocene age in most places, but locally suggest a Pliocene(?) age. Thickness unknown

\section{MESOZOIC SEDIMENTARY ROCKS}

\section{Kandik Group (Lower Cretaceous)}

Kathul Graywacke (Lower Cretaceous)Poorly sorted, olive-green to greenishgray, feldspathic, graywacke sandstone, conglomerate, and argillite, all characteristically with volcanic clast components and chloritic alteration. Provisionally assigned an Early Cretaceous (Albian) age by Brabb (1969) based on indirect evidence. Thickness ranges from $450 \mathrm{~m}$ to $1,000 \mathrm{~m}$

Biederman Argillite (Lower Cretaceous)Rhythmically interbedded dark-gray argillite and medium-gray quartz-rich sandstone and siltstone. Pelecypods of Valanginian age occur near base. Thickness of at least $1,500 \mathrm{~m}$ reported by Brabb (1969) 
quartzite interbeds. Stratigraphic relation with Kandik Group is uncertain

Glenn Shale (Lower Cretaceous to Middle Triassic)

KJgu Upper part (Lower Cretaceous and Jurassic)-Grayish-black carbonaceous shale, with subordinate siltstone and quartzite. Contains fossils of Valanginian, Berriasian, and probable Jurassic age. Estimated thickness ranges from $150-1,500 \mathrm{~m}$

Kgl Lower part (Upper and Middle Triassic)-Thin-bedded, medium- to darkgray, fossiliferous limestone and gray calcareous shale. Abundant pelecypods in places. Estimated thickness generally $150 \mathrm{~m}$ or less, but locally as much as $800 \mathrm{~m}$

\section{MESOZOIC AND (OR) PALEOZOIC METAMORPHIC ROCKS}

$\mathrm{M}_{2} \mathrm{P}_{2 \mathrm{~m}} \quad$ Metamorphic rocks, undivided (Mesozoic and (or) Paleozoic)-Mainly phyllitic siliceous to carbonaceous argillite, argilliceous chert and chert, locally containing abundant greenstone interlayers and lenses, and less common mafic or ultramafic rocks, and tuff. Typically blastomylonitic. Mapped only south of Tintina fault in the southwest corner of the map

\section{PALEOZOIC SEDIMENTARY ROCKS}

$\mathrm{Pt} \quad$ Tahkandit Limestone (Permian)-Massive, cliffforming, light-gray to pale-orange, coarse-grained bioclastic limestone, locally with lenses of chert-pebble conglomerate and grit in carbonate matrix. Abundantly fossiliferous in most places. Thickness 100-125 m

Ps Step Conglomerate (Permian)-Chert-quartzitepebble- and cobble-conglomerate and quartzite; well-rounded clasts set in matrix of chert arenite. White, gray, and green chert clasts predominate; black argillite clasts subordinate. Limestone in lower part has Tahkandit fauna. Thickness of about 600 m estimated by Brabb (1969).

Limestone (Permian)-Massive, lightgray, bioclastic limestone with abundant lenses of chert-rich grit and pebble conglomerate; occurs in one or more beds within lower part of Step Conglomerate; forms basal bed in most places. Individual beds variable in thickness but generally range from $10-50 \mathrm{~m}$.

PMcb Calico Bluff Formation (Lower Pennsylvanian and Upper Mississippian)-Rhythmically interbedded dark-brownish-gray and brownish-black limestone and shale. Contains rich invertebrate fauna, as well as sparse pollen and spores. Estimated thickness about $300 \mathrm{~m}$

MDf

Ford Lake Shale (Upper Mississippian to Upper Devonian)-Thin-bedded, laminated, grayish-black or brown siliceous shale and chert, with characteristic bronze- to light-grayish-orange-weathering color. Abundant plant debris. Thickness of about 600 m estimated by Brabb (1969)

Dnr Nation River Formation (Upper Devonian)-Interbedded olive-gray mudstone, chert-quartz arenite and wacke, and chert-quartzite grit and pebble- to cobbleconglomerate; varicolored chert clasts. Graded bedding common. Dated primarily by spores. Estimated thickness ranges from $600-1,200 \mathrm{~m}$

Dm McCann Hill Chert (Upper to Lower Devonian)-Thin-bedded, laminated, dark-gray, light- to silvery-gray-weathering chert and siliceous argillite; with subordinate chert gritstone. Typically weathers to small chips. Contains sparse conodonts and unidentifiable plant fragments. Basal part contains bioclastic limestone with rich and varied fauna of Emsian (Early Devonian) to Eifelian(?) (Middle Devonian) age. Estimated thickness ranges from $60-250 \mathrm{~m}$

Do. Ogilvie Formation of Clough (1980) (Middle and Lower Devonian)-Massive, medium-gray, bioclastic limestone, with coral-stromatoporoid buildups. Thickness ranging from $60-1,100 \mathrm{~m}$ reported by Clough and Blodgett (1984)

DOr Road River Formation (Lower Devonian to Lower Ordovician)-Dark-gray, carbonaceous, graptolitic shale, with subordinate thin interbeds of gray laminated chert, gray limestone, and chert arenite. Estimated thickness ranges from $125-275 \mathrm{~m}$

o€jr Jones Ridge Limestone (Upper or Middle Ordovician to Lower Cambrian)Mainly massive, extensively silicified, ridge-forming, white to light-gray limestone and dolomite; commonly oolitic to pisolitic, and laminated. Upper part thinner bedded and pale-yellowishbrown. Contains archaeocyathids in lower part. Estimated thickness about $915 \mathrm{~m}$

ofh Hillard Limestone (Lower Ordovician to Lower Cambrian)-Laminated, thick-bedded to massive-bedded, light-yellowish-gray to yellowish-brown limestone, with interbeds of edgewise limestone conglomerate, oolitic limestone, and sandy limestone; 
includes minor dolomite, dark-gray chert, and fissile shale, and a basal carbonate boulder-conglomerate. Brachiopods and trilobites are common. Thickness 65-155 m

Adams Argillite (Lower Cambrian)-Thinbedded, olive-green to yellow-brown argillite, siltstone, and cross-laminated quartzite; has minor yellow-brown sandy limestone interbeds in lower part that contain trilobites and archaeocyathids. Argillite contains detrital sericite. Trace fossil Oldhamia occurs in rocks of similar lithology correlated by Churkin and Brabb (1965b) with the Adams Argillite. Thickness generally 90-165 m, but locally as much as $250 \mathrm{~m}$

Funnel Creek Limestone (Lower Cambrian)-Massive, extensively silicified, cliff-forming, light-gray limestone and dolomite; commonly oolitic and laminated. Non-fossiliferous. Estimated thickness generally ranges from $150-410 \mathrm{~m}$

\section{CAMBRIAN(?) AND PRECAMBRIAN SEDIMENTARY AND IGNEOUS ROCKS}

\section{Tindir Group (Lower Cambrian? to Middle Proterozoic)}

Upper part-Most likely forms a complexly interlensing, possibly rift-controlled sequence characterized by locally abrupt facies changes, but stratigraphic relations not adequately defined by present or previous mapping of Tindir Group

€Ztu Upper part, undivided (Lower Cambrian? and Late Proterozoic)-Argillite, quartzite, dolomite, dolarenite, carbonate-clast conglomerate, red beds, basalt, and black limestone. Thickness at least several hundred meters

EZtq Quartzite (Lower Cambrian? and Late Proterozoic)-Thin- to medium-bedded, fine-to medium-grained, yellow-brown to reddish-brown quartzite, with subordinate cleaved argillite and siltite. Locally, the quartzite is cross-bedded, has calcareous matrix, and (or) contains black argillite or chert grit. Thickness at least several hundred meters

EZtlq Limestone and quartzite (Lower Cambrian? and Late Proterozoic)-Black, platy limestone and yellowbrown to reddish-brown fine-grained quartzite. Thickness at least several hundred meters

€Ztqa Quartzite and argillite (Lower Cambrian? and Late Proterozoic)-Interlayered, blocky, fine- to medium-grained, yellowbrown to reddish-brown quartzite, siltite, and subordinate argillite; quartzite
Thickness at least several hundred meters Red beiss and quartzite (Lower Cambrian? and Late Proterozoic)-Thinly interbedded, generally cleaved, red-brown, maroon, olive-green, yellow-brown, and gray shale, siltstone, slate, fine-grained, cross-bedded quartzite, and argillite with detrital sericite. Locally contains lenses of basalt and volcanic agglomerate, with clasts of jasper, :quartzite, and chert in a reddish, muddy, locally calcareous, tuffaceous volcanic matrix. Contains minor black platy limestone. Oldhamia, a trace fossil considered by Churkin and Brabb (1965b) to be of Cambrian age, occurs at several localities, indicating either that this unit is partly Cambrian in age, or that the age range of Oldhamia extends into the Late Proterozoic. Thickness at least several hundred meters

EZtbs Basalt and sedimentary rocks of Washington Creek (Lower Cambrian? and Late Proterozoic)-Tuffaceous basalt and volcanic conglomerate and interbedded argillite, quartzite, and pebble-conglomerate. Tuffaceous rocks include tuff breccia and conglomerate containing pebbles and cobbles of lithic tuff, vesicular basalt or andesite, and black chert in a tuffaceous matrix. Clastic rocks include greenish-gray to dark-gray or black slaty argillite, fine- to medium-grained cross-bedded quartzite, chert-pebble conglomerate, and minor black limestone. Age uncertain; volcanic rocks could possibly be a facies of the Devonian Woodchopper Volcanics, exposed in the western Charlie River $1: 250,000$ quadrangle, and interfingering sedimentary rocks could be Devonian Nation River Formation. Thickness at least several hundred meters

Ztdl . Dolomite and limestone (Late Proterozoic)-Platy to massive, light- to mediumgray or brownish-gray, pale-orangeweathering, laminated, fine-grained dolomite, silty dolomite, and dolarenite, and platy gray limestone. Minor gray shale and limy shale interbeds. Upper part contains platy limy mudstone, and boulder conglomerate consisting of boulders up to $30 \mathrm{~cm}$ across of cryptocrystalline gray limestone, chert, black argillite and limy argillite in limy dolomite or shale matrix. Lower part has edgewise conglomerate. Thickness at least several hundred meters. Locally includes:

Ztdls Shale-Dark-gray, locally maroon, shale, yellow-brown quartzite, and minor grit; forms mappable interbed. Estimated thickness $200 \mathrm{~m}$ or less 
Laminated limestone (Late Proterozoic)-Platy, black, medium-gray-weathering laminated limestone. Estimated maximum thickness $100 \mathrm{~m}$

Limestone and conglomeratic rocks (Late Proterozoic)-Platy to blocky, dark-gray, medium-gray-weathering limestone; locally is cross-bedded, has petroliferous odor, or contains black chert nodules. In places, contains much gritty clastic material distributed in limy matrix, and locally contains conglomeratic layers or lenses with sandy dolomite, chert, or quartzite clasts in a matrix of limy or sandy dolomite. Estimated maximum thickness approximately $150 \mathrm{~m}$

Dolomite (Late Proterozoic)-Massive, laminated, locally silicified, light-yellowgray to medium-gray, pale-orangeweathering, fine-grained dolomite; contains locally abundant dark, cleaved mudstone and argillite interbeds. Intruded by diabase dikes(d). Thickness at least several hundred meters

Limestone (Late Proterozoic)-Mediumbedded to platy, orange-spotted to mottled, light-gray-weathering limestone. Thickness at least $150 \mathrm{~m}$

Basalt and red beds, undivided (Late Proterozoic)

Red beds-Typically cleaved, thinly laminated, interbedded, red-brown to maroon (hematitic), green or gray mudstone, siltstone, and fine-grained quartzite; well-developed graded bedding in places. Locally includes lenses of basalt or volcanic agglomerate containing clasts of jasper, quartzite, and chert in red muddy, locally dolomitic, tuffaceous volcanic matrix. Also contains minor black platy limestone interbeds. Thickness unknown but at least several hundred meters

Basalt-Massive, locally pillowed, amygdaloidal basalt with calcite amyg-

dules, and minor red mudstone with tuffaceous and calcareous interbeds. Thickness highly variable, but attains several hundred meters locally

Ztba

Ztbc

Ytsh

YtsI

\footnotetext{
${ }^{1}$ Eberlein, G. D., and Lanphere, M. A., in press, Precambrian rocks of Alaska-a review in Harrison, J. E., and Peterman, Z. E., eds., Introduction to correlation of Precambrian rock sequences: U.S. Geological Survey Prof. Paper 1241-B
} 